\title{
Pengembangan Pendidikan Multikultur Dalam Pembelajaran Bahasa Indonesia di Sekolah Dasar
}

\author{
G.A. Putu Sukma Trisna1 \\ ${ }^{1}$ Universitas Pendidikan Ganesha
}

\begin{abstract}
Abstrak
Penelitian ini bertujuan untuk melakukan inovasi pengembangan materi dan model pendidikan multikultur dalam konteks pembelajaran Bahasa Indonesia di Sekolah Dasar. Secara rinci, tujuan penelitian ini adalah: 1) mengidentifikasi kesiapan personal dan profesional guru dalam melaksanakan pendidikan multikultur dalam pembelajaran Bahasa Indonesia, 2) mengidentifikasi dan memformulasikan struktur materi pendidikan multikultur yang layak dikembangkan dalam pembelajaran Bahasa Indonesia di sekolah dasar, 3) memetakan dan menganalisis instrumen penilaian yang selama ini dikembangkan oleh guru dalam pendidikan multikultur pada pembelajaran Bahasa Indonesia di Sekolah Dasar, serta 4) memetakan dan menganalisis hambatan utama guru dalam mengembangkan pendidikan multikultur pada pembelajaran Bahasa Indonesia. Penelitian ini menggunakan desain penelitian dan pengembangan dengan instrumen pengumpul data berupa pedoman observasi, pedoman wawancara, tes hasil belajar, dan angket terbuka. Hasil penelitian menunjukkan bahwa: 1) sekolah dan guru telah memiliki kesiapan yang cukup signifikan untuk dilibatkan dalam pengembangan model pendidikan multikultur, 2) pengorganisasian materi pendidikan multikultur saat ini masih terintegrasi dengan materi Bahasa Indonesia serta bersifat sparated, 3) penilaian yang saat ini dikembangkan oleh guru lebih mengacu pada penilaian produk atau hasil belajar dengan menggunakan tes tertulis bentuk uraian dan isian singkat, 4) hambatan utama guru dalam mengembangkan pendidikan multikultur adalah kurangnya pengetahuan dan keterampilan mereka tentang model-model pendidikan multikultur dan terbatasnya media pembelajaran yang bisa digunakan untuk memfasilitasi pengalaman-pengalaman personal dan sosiokultural siswa dalam kehidupan masyarakat, yang mencakup: konsepsi sosial, konsepsi kultural, dan konsepsi personal dalam balutan pembelajaran Bahasa Indonesia.
\end{abstract}

Kata Kunci:

Pendidikan multikultur,

Bahasa Indonesia,

Sekolah Dasar

\section{Pendahuluan}

Perkembangan ilmu pengetahuan dan seni (IPTEKS) telah menghadirkan tantangan dan sekaligus peluang baru bagi umat manusia dalam segala dimensi kehidupannya. Kondisi ini semakin diperkuat oleh semakin menggejalanya warna kehidupan global, sehingga setiap manusia dan bangsa harus selalu siap untuk melakoni kehidupan global yang tanpa batas. Globalisasi merupakan implikasi logis dari kemajuan IPTEKS. Revolusi informasi dan komunikasi sebagai dampak langsung dari kemajuan IPTEKS telah menghilangkan batasan-batasan region dan kewilayahan, sehingga bagi masyarakat tertentu, kondisi ini harus disikapi dengan cepat dan komprehensif sehingga mereka tidak kehilangan jati diri bangsa dan negaranya. Bagi bangsa Indonesia, kondisi tersebut tentu merupakan realitas yang harus disikapi secara seksama dan sesegera mungkin, mengingat karakteristik geografis dan sosial-budaya yang sangat beragam. Keberagaman suku, agama, etnis, dan bahasa telah menjadi warna abadi bangsa Indonesia. Oleh sebab itu, pemahaman terhadap keragaman oleh setiap masyarakat merupakan sebuah kewajiban. Negara multikultural seperti Indonesia harus antisipatif dan responsif terhadap fenomena heterogenitas kebudayaan dengan sikap arif dan bijak. Perbedaan yang selama ini ada, pada satu sisi telah menimbulkan dampak negatif berupa konflik yang melanda negeri ini, yang salah satunya disebabkan heterogenitas atau deferensiasi sosial pada masyarakat. Keberadaan mata pelajaran Bahasa Indonesia juga belum cukup untuk menanamkan kesadaran multikulturalisme. Pada sisi yang lain, kita pun merasakan bahwa Bahasa Indonesia yang diberikan di sekolah pada umumnya tidak menghidupkan pendidikan multikultural yang baik, bahkan cenderung kontraproduktif dengan misi pendidikan keberagaman tersebut. 
Terkait dengan hal di atas, bila kita merefleksi dan memprediksi tantangan kehidupan global dan pentingnya menjaga stabilitas serta integritas bangsa, maka ada sejumlah strategi pendidikan yang harus dikembangkan seperti: peningkatan pendidikan moral dan budi pekerti, penanaman pemahaman dan kesadaran (literasi) terhadap keberagaman kultur kebangsaan, perbaikan kualitas proses dan produk pembelajaran, penyiapan perangkat instruksional yang mendukung peningkatan mutu pendidikan, dan hal-hal lain yang bersifat mikro seperti pengembangan model dan strategi pembelajaran yang visibel bagi pembelajara multikultur. Berdasarkan rasional di atas, maka penelitian ini akan diarahkan pada upaya pengembangan model dan perangkat pendidikan multikultur, sehingga produk penelitian ini dapat digunakan oleh para guru dalam melaksanakan pendidikan multikultur yang terintegrasi secara holistik dalam satuan mata pelajaran.

Indonesia adalah negara multikultural dengan keanekaragaman agama, adat istiadat, budaya, dan suku bangsa. Keanekaragaman tersebut merupakan kekayaan dan aset yang sangat berharga. Namun, masih terdapat dampak negatif akibat keanekaragaman tersebut. Sebagai contoh, masih ditemukan konflik antar agama maupun suku bangsa. Kasus yang menonjol adalah konflik antar etnis Madura dan Dayak di Kalimantan. Perbedaan agama menjadi salah satu pemicu terjadinya konflik di Ambon dan Sulawesi. Kedua konflik tersebut merupakan sebagian dari kasus bagaimana suatu perbedaan menimbulkan dampak negatif. Seharusnya keberagaman yang ada dalam tubuh bangsa Indonesia akan menjadi kekuatan yang tangguh apabila diolah secara baik dan benar. Terjadinya konflik, baik antar etnis di Kalimantan maupun antar agama di Ambon dan Sulawesi bukan disebabkan semata oleh benturan alamiah masyarakat di tingkat lokal. Dimensi politik, ekonomi, dan kebijakan pemerintah memiliki peran tersendiri. Ketidakadilan akibat distribusi yang tidak merata, kebijakan pemerintah dalam segala bidang yang cenderung trickle down sangat rentan menjadi pemicu munculnya konflik horizontal.

Bagaimana mengatasi problematika negatif sebagai implikasi dari karakteristik kebangsaan yang multietnis?. Bertalian dengan masalah tersebut, salah satu instrumen instruksional penting dalam konteks pendidikan formal adalah melalui Bahasa Indonesia. Pembelajaran Bahasa Indonesia sangat besar pengaruhnya dalam membentuk kesadaran dan karakter bangsa. Secara substansial, Bahasa Indonesia dapat mengembangkan kesadaran multikultural yang bersifat normatif dan interatif. Apakah implementasi pendidikan yang dilaksanakan selama ini telah mencapai taraf normati?, atau sekadar pendidikan multikultural deskriptif, yang menekankan pada pemberian penjelasan bagaimana bangsa Indonesia dengan Bhinneka Tungga Ika layaknya mutiara di katulistiwa?, atau slogan-slogan heroik lainnya?.

Pendidikan multikultural adalah merupakan gerakan pembaharuan dan proses untuk menciptakan lingkungan pendidikan yang setara untuk seluruh siswa. Sebagai sebuah gerakan pembaharuan, istilah pendidikan multikultural masih dipandang asing bagi masyarakat umum, bahkan penafsiran terhadap definisi maupun pengertian pendidikan multicultural juga masih diperdebatkan di kalangan pakar pendidikan. Pendidikan multikultur merupakan konsep pendidikan yang muncul pada masa setelah berakhirnya perang dunia ke-2. Pendidikan multikultur merupakan gejala baru di dalam pergaulan umat manusia yang mendambakan persamaan hak, termasuk hak untuk mendapatkan pendidikan. Pendidikan multikultur menjadi acuan beberapa negara, baik di Amerika, Eropa, Asia, dan Australia yang penduduknya relatif heterogen. Seperti pendapat Andersen dan Cusher (1994) sebagaimana dikutip Mahfud (2008), bahwa pendidikan multicultural diartikan sebagai pendidikan mengenai keragaman kebudayaan. Sedangkan Hernandez (1989), mengartikan pendidikan multikultural sebagai perspektif yang mengakui realitas sosial, politik, dan ekonomi yang dialami oleh masing-masing individu dalam pertemuan manusia yang kompleks dan beragam secara kultur, dan merefleksikan pentingnya budaya, ras, seksualitas dan gender, etnisitas, agama, status social, ekonomi, dan pengecualian-pengecualian dalam proses pendidikan.

Ahli lain, Sleeter dan Grant (2009) dan Smith (1998) sebagaimana dikutip Zamroni (2011) mendefinisikan pendidikan multikultural sebagai suatu pendekatan progresif untuk melakukan transformasi pendidikan yang secara holistik memberikan kritik dan menunjukkan kelemahankelemahan, kegagalan-kegagalan dan diskriminasi yang terjadi di dunia pendidikan (Zamroni, 2011: 144). Frazier dan Garcia (2014:122), menyatakan bahwa yang dimaksud dengan pendidikan multikultur adalah: ".. is a concept frame work, a way of thinking, a philosophycal view point, a value orientation, and a set of criteria for making decission that better genie the educational needs of culturally diverse student populations". Sementara Appiah (2004) menyatakan bahwa pendidikan multikultur menekankan pada kesederajatan dalam memperoleh kesempatan pendidikan kepada seluruh masyarakat yang memasukkan seluruh partisipasi siswa dalam berbagai hal, seperti yang ia ungkapkan sebagai berikut: "We may define multicultural education as a field study designed to increase educational equity for all students that incorporates, for this purpose, content, concepts, principles, theories, and paradigms from history, the social and behavioral sciences, and particulary from ethnic studies and women studies". Berlandaskan pada 
preposisi tersebut, yang dimaksud dengan pendidikan multikultur adalah proses penanaman cara hidup menghormati, tulus, dan toleran terhadap keanekaragaman budaya yang hidup di tengah-tengah masyarakat plural.

Melalui pendidikan multikultur, diharapkan adanya kekenyalan dan kelenturan mental bangsa menghadapi konflik sosial, sehingga kesatuan dan persatuan bangsa tidak mudah patah dan retak. Mempertegas preposisi tersebut, Oliver (2011) menyatakan bahwa: "Multicultural education nonetheless represents a change in educational thinking, because that is can help individuals and communities value and preserve their own cultural uniqueness, so can serve the same function more generally".

Secara tipologis, menurut Banks (1995) terdapat lima model pendidikan multikultur yang lazim dikembangkan dan diaplikasikan di beberapa Negara, yaitu: 1) mengajar kelompok siswa yang memiliki budaya yang lain (cultural difference); 2) hubungan manusia (human relation), membantu siswa dalam melakukan percampuran antarkelompok; 3) single group studies, yakni program yang mengajarkan halhal yang memajukan pluralisme tetapi tidak menekankan adanya stratifikasi sosial dalam masyarakat; 4) pendidikan multikultur melalui reformasi pendidikan yang menyediakan kurikulum serta materi pelajaran yang menekankan kepada adanya perbedaan siswa dalam bahasa, yang keseluruhannya untuk memajukan pluralisme kebudayaan dan equalitas social; 5) pendidikan multikultural yang sifatnya rekonstruksi sosial, dengan tujuan menyatukan keberagaman dan menantang ketimpangan sosial yang ada dalam masyarakat. Bagaimana membangun konsep pendidikan multikultur untuk Indonesia?. Tentu pertanyaan tersebut bukan persoalan mudah untuk dicari jawabannya. Menyadari bahwa tantangan globalisasi dan revolusi telekomunikasi yang semakin menggejala, maka konsep dan model pendidikan multikultur untuk Indonesia telah menjadi kebutuhan dasar pendidikan untuk dikembangkan.

\section{Metode}

Untuk keseluruhan tahap penelitian, di samping dilaksanakan sepenuhnya oleh tim peneliti, juga melibatkan mahasiswa PGSD, mulai dari diskusi saat penyusunan proposal serta membantu pengumpulan dan tabulasi data. Penelitian ini dilakukan pada sekolah dasar yang tersebar di 9 kecamatan yang ada di kabupaten Buleleng. Besaran sampel sekolah pada setiap tahapannya akan disesuaikan dengan kebutuhan data dan keluasan uji empiris model. Untuk menjaring data penelitian digunakan beberapa instrumen, yaitu lembar pedoman observasi, pedoman wawancara, studi dokumentasi, kuesioner terbuka dan tertutup, serta focus group discussion. Keseluruhan data dianalisis dengan menggunakan beberapa teknik, yaitu data yang bertalian dengan dinamika proses dan personal aktivitas responden dianalisis secara deskriptif, sementara data yang terkait dengan orientasi dan fakta lapangan pendidikan multikultur dianalisis dengan menggunakan metode critical content apraisal (CCA) yang dipadukan dengan region respons apraisal. Sementara, data yang terkait dengan efektivitas model terhadap capaian prestasi belajar siswa dan keterampilan multikulturnya dianalisis dengan menggunakan Anakova.

\section{Hasil dan Pembahasan}

Secara administratif-pedagogis, sekolah dan guru sekolah dasar di Kabupaten Buleleng telah memiliki kesiapan yang signifikan dalam pengembangan pendidikan multikultur yang diintegrasikan dalam pembelajaran Bahasa Indonesia. Secara personal, kesiapan ini dinyatakan melalui respons yang sangat positif ketika peneliti mewawancarai mereka dan melakukan observasi langsung ketika dilakukan pembelajaran Bahasa Indonesia pada masing-masing sekolah sampel. Sementara secara kelembagaan, kepala sekolah dengan sangat terbuka menyatakan kesiapannya untuk mendukung dan membantu pelaksanaan pengembangan pendidikan multikultur di sekolah yang dipimpinnya. Kedua indikator tersebut dapat dijadikan sebagai dasar kesiapan sekolah dan guru dalam mengembangkan model pendidikan multikultur yang menjadi fokus dalam penelitian ini.

Secara paradigmatik pengorganisasian materi pendidikan multikultur dalam pembelajaran Bahasa Indonesia yang saat ini dilakukan oleh guru lebih disandarkan pada program pendidikan terintegrasi yang bersifat pedagogis, sosiokultural, dan psikologis, yang bertujuan memfasilitasi siswa mengembang-kan kompetensi-kompetensi dasar personal, sosial dan intelektualnya yang dibutuhkan untuk meng-konstruksi dan me-rekonstruksi keberagaman dan keberbedaan diri dan lingkungannya secara berkesinambungan dalam struktur pengetahuan, nilai, sikap, dan tindakannya dalam berbagai latar kehidupan pribadi, sosial dan kultural. Fakta di lapangan ternyata menunjukkan bahwa: guru belum mampu mengembangkan dan membelajarkan kompetesi pendidikan multikultur (Lasmawan, 2005). Mereka masih menekankan pada konsep dasar keilmuan dari materi tersebut, dengan mengabaikan "theother targets" dari candraan kompetensi yang ada pada struktur kurikulum, yaitu pendidikan multikultur. Hal ini terjadi, karena guru belum memiliki kemampuan dan keterampilan mengembangkan, 
mengorganisir, dan membelajarkan serta menilai kompetensi pendidikan multikultur (Lasmawan, 2005; Hasan, 2005). Penelitian yang dilakukan oleh Lasmawan (2005) tentang pengembangan model pendidikan nilai dalam pembelajaran IPS menunjukkan bahwa: hampir $65 \%$ guru tidak memiliki kurikulum mata pelajaran yang dibinanya, dan pembelajaran yang dilakukan sangat gersang dengan pesan nilai moral realistik yang sangat dibutuhkan oleh siswa dalam kehidupannya sehari-hari.

Sementara materi pendidikan multikultur belum berdiri sendiri sebagai sebuah topik mandiri, melainkan terintegrasi secara holistik dalam sebaran materi pembelajaran Bahasa Indonesia. Sementara, kompetensi-kompetensi pendidikan multikultur yang dikembangkan oleh guru selama ini bertalian dengan kesadaran, kebersamaan, toleransi, demokrasi, kebudayaan, dan idiologi.

Model penilaian materi pendidikan multikultur yang selama ini dikembangkan oleh guru dalam pembelajaran Bahasa Indonesia lebih banyak bersandar pada penilaian produk dengan menggunakan instrumen penilaian berupa tes hasil belajar bentuk uraian dan menjawab singkat. Pola dan instrumen penilaian yang dominan menggunakan tes tertulis dan hanya dilakukan pada akhir pembelajaran, kurang relevan dengan karakteristik pendidikan multikultur yang lebih menekankan pada keterampilan proses dan sikap yang dinamis selama berlangsungnya pembelajaran. Realitas ini merupakan peluang terbuka dan sangat memungkinkan untuk mengembangkan model penilaian yang lebih komprehensif dan membumi dalam pendidikan multikultur yang diintegrasikan dalam pembelajaran Bahasa Indonesia di sekolah sampel.

Hambatan mendasar yang saat ini dialami oleh guru dalam membelajarkan materi pendidikan multikultur delalui pembelajaran Bahasa Indonesia adalah: 1) terbatasnya kemampuan dan keterampilan instruksional guru itu sendiri; 2) terbatasnya sarana dan prasarana pembelajaran yang dapat dijadikan sebagai media pembelajaran multikultur; 3) jumlah kelas yang relatif gemuk dengan siswa di atas 45 orang sangat menyulitkan guru dalam melakukan layanan belajar dan mengelola kelas; 4) model-model pembelajaran pendidikan multikultur yang ada di sekolah sangat terbatas, dan 5) sebaran standar kompetensi dan kompetensi dasar Bahasa Indonesia sangat sulit untuk dikemas secara sparated sehingga guru tidak bisa membelajarkan pendidikan multikultur dalam kemasan materi tersendiri.

Model konseptual pendidikan multikultur yang dikembangkan dalam penelitian ini, struktur isi materinya tidak disusun berdasarkan struktur isi disiplin ilmu, melainkan dilakukan dengan merujuk pada pertimbangan, sejauh mana materi tersebut memiliki relevansi dengan struktur internal siswa yang dibangun dari hasil pengalaman-pengalaman personal dan sosiokulturalnya di dalam kehidupan masyarakat, yang mencakup: 1) konsepsi sosial, yang secara eklektik memuat pengetahuan "fungsional" dan "non-fungsional" tentang keberagaman lingkungannya; 2) konsepsi kultural, yang secara eklektik memuat struktur sintaksis budaya keseharian siswa dan struktur sintaksis pengalaman dirinya dalam kehidupan bermasyarakat, dan 3) konsepsi personal, yang memuat nilai-nilai, norma-norma, dan sikapsikap, yang sudah menjadi personal belief dan realitas masyarakatnya, dan nilai-nilai, norma-norma, dan sikap-sikap personal dan sosiokultural siswa sebagai mahluk yang pribadi dalam balutan mata pelajaran Bahasa Indonesia.

Berdasarkan fakta/data tersebut, pengembangan desain model dan materi pendidikan multikultur lebih didasarkan pada prinsip "a student's psychological, sociocultural, and intellectual horizons reconstructions character-based", bukan berdasarkan pada "structure of discipline". Hal ini dilakukan dengan tujuan organisasi dan struktur materi pendidikan multikultur lebih kontekstual, relevan, dan bermakna bagi siswa, dan tidak merusak "indigenous structure" yang telah terbentuk dan berkembang pada diri siswa.

Berlandaskan pada temuan penelitian tersebut, pendidikan multikultur dalam pembelajaran Bahasa Indonesia sekolah dasar di Kabupaten Buleleng pada dasarnya telah merujuk pada esensi dari pendidikan multikulur itu sendiri, yang mana para guru secara personal maupun profesional telah memasukkan unsur keberagaman dalam pembelajaran Bahasa Indonesia, hanya secara akademis belum terstruktur. Model konseptual pendidikan multikultur yang akan dikembangkan dalam penelitian tahun kedua (tahun 2008) berdasarkan analisis kebutuhan yang telah dilakukan pada dasarnya struktur isi materinya tidak disusun berdasarkan struktur isi disiplin ilmu, melainkan sejauh memiliki relevansi dengan struktur internal siswa yang dibangun dari hasil pengalaman-pengalaman personal dan sosiokulturalnya di dalam kehidupan masyarakat, yang mencakup: 1) konsepsi sosial, yang secara eklektik memuat pengetahuan "fungsional" dan "non-fungsional" tentang keberagaman lingkungannya; 2) konsepsi kultural, yang secara eklektik memuat struktur sintaksis budaya keseharian siswa dan struktur sintaksis pengalaman dirinya dalam kehidupan bermasyarakat, dan 3) konsepsi personal, yang memuat nilai-nilai, norma-norma, dan sikap-sikap, yang sudah menjadi belief dirinya dan realitas masyarakatnya, dan nilai-nilai, norma-norma, dan sikap-sikap personal dan sosiokultural siswa sebagai mahluk yang pribadi dalam balutan mata pelajaran Bahasa Indonesia 


\section{Simpulan dan Saran}

Secara administratif-pedagogis, sekolah dan guru sekolah dasar di Kabupaten Buleleng telah memiliki kesiapan yang signifikan dalam pengembangan pendidikan multikultur yang diintegrasikan dalam pembelajaran Bahasa Indonesia. Berdasarkan analisis data dan pembahasan yang telah dilakukan, simpulan penelitian ini dapat dirumuskan sebagai berikut: 1) sekolah dan guru telah memiliki kesiapan yang cukup signifikan untuk dilibatkan dalam pengembangan model pendidikan multikultur, 2) pengorganisasian materi pendidikan multikultur saat ini masih terintegrasi dengan materi Bahasa Indonesia serta bersifat sparated, 3) penilaian yang saat ini dikembangkan oleh guru lebih mengacu pada penilaian produk atau hasil belajar dengan menggunakan tes tertulis bentuk uraian dan isian singkat, 4) hambatan utama guru dalam mengembangkan pendidikan multikultur adalah kurangnya pengetahuan dan keterampilan mereka tentang model-model pendidikan multikultur dan terbatasnya media pembelajaran yang bisa dignakan untuk memfasilitasi pengalaman-pengalaman personal dan sosiokultural siswa dalam kehidupan masyarakat, yang mencakup: konsepsi sosial, konsepsi kultural, dan konsepsi personal dalam balutan pembelajaran Bahasa Indonesia.

\section{Daftar Pustaka}

Alwasilah, A.C. (2006). Pokoknya Kualitatif. Jakarta: Pustaka Jaya.

Aly, Abdullah. (2005). "Pendidikan Multikultural dalam Tinjauan Pedagogik". Makalah dipresentasikan pada Seminar Pendidikan Multikultural sebagai Seni Mengelola Keragaman, yang diselenggarakan oleh Pusat Studi Budaya dan Perubahan Sosial (PSB-PS) Universitas Muhammadiyah Surakarta.

Andersen dan Cusher. (1994). Multicultural and Intercultural Studies, dalam Teaching Studies Of Society And Environment (ed. Marsh, C) Sydney: Prentice-Hall.

Appiah, K. A. (2004). Identity, Authenticity, Survival: Multicultural Societies and Social Reproduction. Dalam Amy Gutmann (Ed), Multiculturalism. Princeton, Ney Jersey: Princeton University Press.

Arsyad Khudri. (2010). Pendidikan Multikultural, Solusi Tepat Atasi Defisit Demokrasi di Indonesia; Suatu Kajian Pendidikan yang Humanis.

Asyar'i, L. (2004). Membebaskan Diri dari Keterikatan Lokal. Kompas.

Banks, J. and Banks. (1995). Teaching strategies for ethnic studies. Boston: Allyn and Bacon.

Banks, James A. (ed.). 1989. Multicultural Education: Issues and Perspectives. Boston-London: Allyn and Bacon Press.

Daniel Winantara, IW., I Nyoman Laba Jayanta. (2017). Penerapan Model Pembelajaran TPS Untuk Meningkatkan Hasil Belajar IPA Siswa Kelas V SD No 1 Mengwitani. Jurnal Ilmiah Sekolah Dasar. Vol. 1 No. 1.

Depdiknas. (2016). Kurikulum Bahasa Indonesia Sekolah Dasar 2016. Jakarta: Departemen Pendidikan Nasional, Dirjen Pendidikan Dasar dan Menengah.

Dodd, C. H. (2008). Dynamics of Intercultural Communication (Tifth Edition). New York: McGraw-Hill.

Dwitha, Evayanti \& Made Sumantri. (2017). Penerapan Metode Mind Mapping Untuk Meningkatkan Keterampilan Menulis Surat Pribadi Siswa Kelas IIIA. Jurnal Ilmiah Sekolah Dasar. Vol.1 (1) pp. 42-50.

Educational for Democracy Project. (2012). Education for democracy. American Federation of Teachers, 313 (5), 57-62.

Febrian Kurniasari, Elisabet., Eunice Widyanti Setyaningtyas. (2017). Peningkatan Hasil Belajar IPS Melalui Penerapan Model Pembelajaran Kooperatif Tipe Think Pair and Share (TPS) dengan Teknik Gallery Walk. Journal of Education Research and Evaluation. Vol. 1 No. 2.

Hernandez, Hilda. (1989). Multicultural Education: A teacher Guide to linking Context, Process, and Content, New Jersy \& Ohio : Prentice Hall.

Lasmawan, W. (2015). Nasionalisme dikalangan masyarakat pedesaan (studi eksploratif pendidikan politik oleh partai politik di Kecamatan Kintamani - Bangli). (Laporan Penelitian). Singaraja: Lembaga Penelitian Undiksha. 
M. Ainul Yaqin. 2005. Pendidikan multikultural Ragita Adiputra, Ida Bagus. (2012). Analisis Butir Soal Tes Ulangan Akhir Semester IPS Terpadu Buatan MGMP IPS Kabupaten Gianyar Kelas VII Semester 1. Jurnal Pendidikan Indonesia. Vol. 1 No. 1.

Septina Witari Dewi, Gusti Ayu Made., Ni Ketut Suarni, I Wayan Widiana. (2014). Pengaruh Model Pembelajaran Tandur Terhadap Hasil Belajar IPA Ditinjau Dari Minat Belajar Siswa. Mimbar PGSD. Vol. 2 No. 1.

Sudiatmika, dan Lasmawan. (2012). Pengembangan Model Pendidikan Multikultur Berbantuan Modul: cross-cultural understanding untuk demokrasi dan keadilan. Yogyakarta: Pilar Media.

Mahfud, A. (2014). Model pengorganisasian materi Bahasa Indonesiadi SMU (Studi kebijakan dalam konteks pendidikan sekolah). (Laporan Penelitian). Palu: Lemlit UNTAD.

Mahfud, C. (2008). Pendidikan Multikultural, Yogyakarta: Pustaka Pelajar.

Maria, H. (2011). Asimilasionisme vs Multikulturalisme. Kompas, 14 Maret 2001.

McCarthy, C. (2014). Multicultural discourses and curriculum reform: A critical perspective. Educational Theory, number 44-vol.1, page 81-83.

O’Sulivan, 1994) T. (Ed). (2014). Key Concept in Communication Cultural Studies. New York: Routledge, Pub.

Tilaar, H.A.R (2004). Multikulturalisme Tantangan-tantangan Global Masa Depan dalam Tranformasi Pendidikan Nasional. Jakarta: Grassindo.

Winatasaputra, U. (2008) "Multikulturalisme Bhinneka Tunggal Ika dalam Perspektif Pendidikan Kewrganegaraan sebagai Wahana Pembangunan Karakter Bangsa Indonesia" dalam Dialog Multikultural untuk Membina Kerukunan Antar Umat Beragama. Bandung: JICA FPMIPA UPI. 